AperTO - Archivio Istituzionale Open Access dell'Università di Torino

Carcinogenicity of fluoro-edenite, silicon carbide fibres and whiskers, and carbon nanotubes

This is a pre print version of the following article:

Original Citation:

Availability:

This version is available http://hdl.handle.net/2318/156828

since

Published version:

DOI:10.1016/S1470-2045(14)71109-X

Terms of use:

Open Access

Anyone can freely access the full text of works made available as "Open Access". Works made available under a Creative Commons license can be used according to the terms and conditions of said license. Use of all other works requires consent of the right holder (author or publisher) if not exempted from copyright protection by the applicable law. 


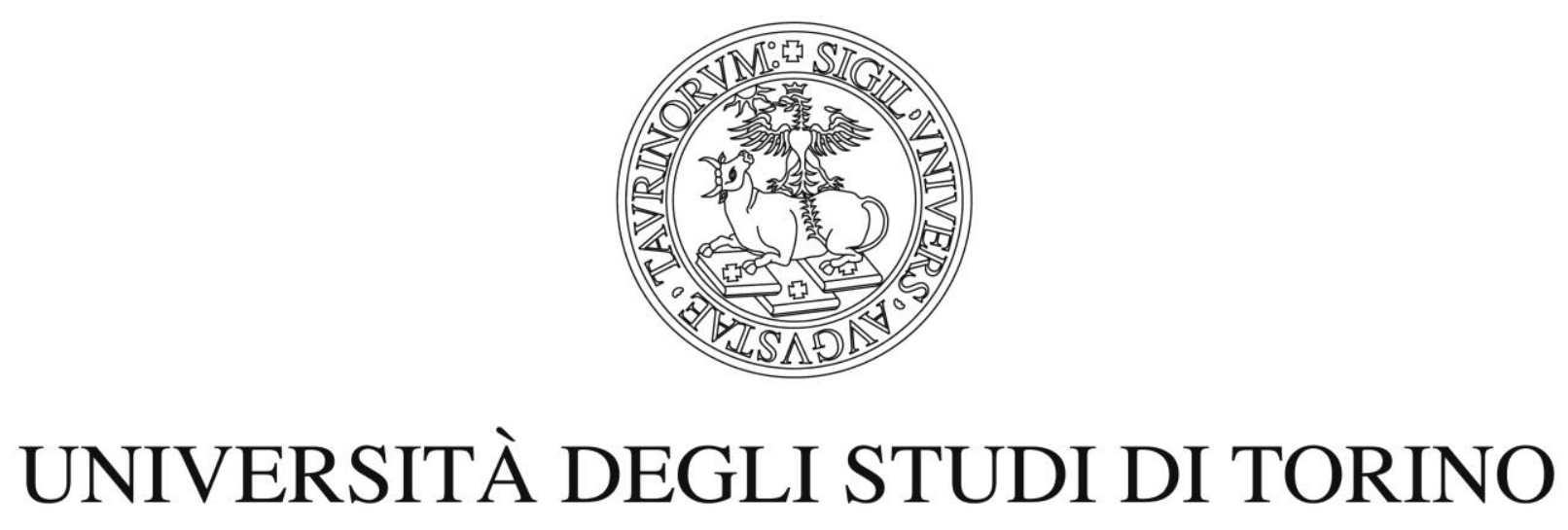

This is an author version of the contribution published on:

Questa è la versione dell'autore dell'opera:

A B Kane et al., Volume 15, No. 13, p1427-1428, December 2014

The definitive version is available at:

La versione definitiva è disponibile alla URL:

http://www. thelancet.com/journals/lanonc/article/PIIS1470-2045\%2814\%2971109-

X/fulltext? eventld 


\title{
Carcinogenicity of fluoro-edenite, silicon carbide fibres and whiskers, and carbon nanotubes
}

\author{
IARC Monograph Working Group Members A B Kane (USA)-Meeting Chair; M Debia; C \\ Dion (Canada); P Møller (Denmark); K Savolainen (Finland); I Gusava Canu; M C \\ Jaurand (France) ; P Comba; B Fubini (Italy); N Kobayashi; Y Morimoto; H Tsuda (Japan); I J Yu \\ (South Korea); R Vermeulen (Netherlands); M D Bugge (Norway); T F Bateson; E D Kuempel; D \\ L Morgan; K E Pinkerton; L M Sargent; L Stayner (USA)
}

In October, 2014, 21 experts from ten countries met at the International Agency for Research on Cancer (IARC; Lyon, France) to assess the carcinogenicity of fluoro-edenite, silicon carbide (SiC) fibres and whiskers, and carbon nanotubes (CNTs) including singlewalled (SWCNTs) and multi-walled (MWCNTs) types. These assessments will be published as Volume 111 of the IARC Monographs.1 Fluoro-edenite was first identified around the Etna volcano near Biancavilla, Italy; a similar mineral was also reported from the Kimpo volcano in Japan. Fluoro-edenite can occur as asbestiform fibres. Unpaved roads made from local quarry products from Biancavilla, used since the 1950s, are a source for airborne fl uoro-edenite fibres; additionally indoor air was also contaminated from the use of the quarry's products in building materials. Several surveillance studies reported an excess of mesothelioma incidence and mortality in the regional population of Biancavilla.2 Since the rate ratios for mesothelioma were large and stable, chance was unlikely to explain these fi ndings. The excess was similar in men and women, and most prominent in young adults, suggesting an environmental rather than occupational cause. Moreover, most of the cases had no history of occupational exposure to asbestos. Fluoro-edenite fi brous amphibole was classifi ed as carcinogenic to humans (Group 1) on the basis of sufficient evidence in humans that exposure to fl uoro-edenite causes mesothelioma. Suffi cient evidence of carcinogenicity was also reported in experimental animals, with increased incidences of mesotheliomas observed in one study in male and female rats given fibrous fluoro-edenite by intraperitoneal or intrapleural injection. 3 The results of the few available mechanistic studies were consistent with proposed mechanisms of fi bre carcinogenicity. $4 \mathrm{SiC}$ occurs in several forms: particles, fibres, and whiskers. SiC particles are manufactured (mostly for use as industrial abrasive) mainly by the Acheson process, with SiC fi bres being unwanted by-products. SiC fi bres are generally poly-crystalline; of variable length and diameter, and may include fibres that are indistinguishable from whiskers. SiC whiskers are intentionally produced by different processes as durable industrial substitutes for asbestos; they 
are physically homogeneous and monocrystalline, and their dimensions are similar to asbestos amphiboles. The carcinogenicity of $\mathrm{SiC}$ fi bres was investigated in two cohorts of Acheson process workers who were exposed to fibrous and non-fibrous $\mathrm{SiC}$, quartz, and cristobalite. In a Canadian cohort study,5 an excess of lung cancer mortality was observed. An excess of lung cancer and an exposure-response relationship with $\mathrm{SiC}$ fibres was described in the most detailed report from a series of studies on cancer incidence in a Norwegian cohort. 6 The analyses were limited to workers with at least 3 years of employment in the plant and based on a detailed jobexposure matrix taking into account multiple exposures. The exposure-response relationship was somewhat weakened after adjustment for exposure to cristobalite. Occupational exposures associated with the Acheson process were classifi ed as carcinogenic to humans (Group 1) on the basis of sufficient evidence in humans that they cause lung cancer. Since the correlation between exposures to SiC fi bres and cristobalite made it diffi cult to disentangle their independent eff ects, the Working Group concluded that fi brous $\mathrm{SiC}$ is possibly carcinogenic to humans (Group 2B) based on limited evidence in humans that it causes lung cancer. No data on cancer in humans exposed to $\mathrm{SiC}$ whiskers were available. In experimental animals, there was suffi cient evidence for the carcinogenicity of $\mathrm{SiC}$ whiskers, with mesotheliomas observed in three studies in female rats treated by intrapleural implantation,7 intrapleural injection, or intraperitoneal injection, and in one inhalation study in rats that did not include concurrent controls. Although not unanimous, the Working Group classified SiC whiskers as probably carcinogenic to humans (Group 2A) rather than possibly carcinogenic to humans (Group 2B), on the basis that the physical properties of the whiskers resemble those of asbestos and erionite fibres, which are known carcinogens. In addition, the results of available mechanistic studies were consistent with proposed mechanisms of fi bre carcinogenicity. 4 The majority of the Working Group considered that diff erences in the nature of $\mathrm{SiC}$ fi bres and $\mathrm{SiC}$ whiskers warranted separate evaluations. Carbon nanotubes may consist of either a single graphene cylinder (SWCNTs) with an outer diameter of 1-3 nm, or of multiple graphene cylinders arranged in concentric layers (MWCNTs) with diameters of 10-200 nm. CNTs are typically few micrometres in length, ranging from a few hundreds of nanometres to several tens of micrometres; their physical and chemical characteristics vary depending on the production technique. Applications include improving the structural properties of fabrics, plastics, rubbers, electronics, and composite materials. The highest release of CNTs, usually as entangled agglomerates which can be respirable, is observed during production and handling, and in cleaning of the production reactor. Measurement of occupational exposure is limited, Carcinogenicity 
and consumer exposure was not quantified. No human cancer data were available to the Working Group, indicating inadequate evidence for the carcinogenicity of CNTs in humans. Some CNTs were tested in rodents. MWCNT-7 caused peritoneal mesotheliomas in male and female rats in one intraperitoneal injection study 8 and one intrascrotal injection study, 9 and in male $p 53+/-$ mice in two intraperitoneal injection studies.10 Inhalation of MWCNT-7 promoted bronchioloalveolar adenoma and carcinoma in male mice.11 In one intraperitoneal study, two other types of MWCNTs with physical dimensions similar to those of MWCNT-7 (length, 1-19 $\mu$ m; diameter, 40-170 $\mathrm{nm}$ ) caused mesotheliomas in male and female rats.8 Two studies with SWCNTs in rats were inconclusive. Regarding carcinogenicity in experimental animals, the Working Group concluded that there was suffi cient evidence for MWCNT-7, limited evidence for the two other types of MWCNTs with dimensions similar to MWCNT-7, and inadequate evidence for SWCNTs. Mechanistic and other data in rodents provided evidence of trans location of three types of MWCNTs (including MWCNT-7) to the pleura.12 Additionally, inhalation of some MWCNTs or SWCNTs induced acute or persistent pulmonary inflammation, granuloma formation, fibrosis, and bronchiolar or bronchioloalveolar hyperplasia in rodents.13,14 Studies in rodents (eg, Shvedova et al15) and in cultured human lung or mesothelial cells showed that MWCNTs, SWCNTs, or both induce genetic lesions such as DNA strand breaks, oxidised DNA bases, mutations, micronucleus formation, and chromosomal aberrations. SWCNTs and MWCNTs also perturb the cellular mitotic apparatus, including microtubules and centrosomes, in human lung epithelial cells.16,17 As a whole, the Working Group acknowledged that the above mechanisms are all relevant to humans. However, a majority did not consider the mechanistic evidence for carcinogenicity - especially concerning chronic endpoints - to be strong for any specifi c CNT. Furthermore, the lack of coherent evidence across the various distinct CNTs precluded generalisation to other types of CNTs. Thus, MWCNT-7 was classifi ed as possibly carcinogenic to humans (Group 2B); and SWCNTs and MWCNTs excluding MWCNT-7 were categorised as not classifi able as to their carcinogenicity to humans (Group 3).

Yann Grosse, Dana Loomis,

Kathryn Z Guyton,

Béatrice Lauby-Secretan,

Fatiha El Ghissassi, Véronique Bouvard,

Lamia Benbrahim-Tallaa, Neela Guha,

Chiara Scoccianti, Heidi Mattock,

Kurt Straif, on behalf of the

International Agency for Research on

Cancer Monograph Working Group

International Agency for Research on Cancer,

Lyon, France 
1 International Agency for Research on Cancer. Volume 111: Fluoro-edenite, silicon carbide fi bres and whiskers, and single-walled and multi-walled carbon nanotubes IARC Working Group. Lyon; 30 Sep-7 Oct 2014. IARC Monogr Eval Carcinog Risk Chem Hum (in press).

2 Bruno C, Tumino R, Fazzo L, et al. Incidence of pleural mesothelioma in a community exposed to fi bres with fl uoro-edenitic composition in Biancavilla (Sicily, Italy). Ann Ist Super Sanita 2014; 50: $111-18$.

3 Belpoggi F, Tibaldi E, Lauriola M, et al. The effi cacy of long-term bioassays in predicting human risks: mesotheliomas induced by fl uoro-edenitic fi bres present in lava stone from Etna Volcano in Biancavilla Italy. Eur J Oncol 2014; 16: 185-95.

4 International Agency for Research on Cancer. Volume 100C: Arsenic, metals, fi bres, and dusts. IARC Working Group. Lyon; 17-24 March 2009. IARC Monogr Eval Carcinog Risk Chem Hum 2012; 100C: 219-316.

5 Infante-Rivard C, Dufresne A, Armstrong B, Bouchard P, Thériault G. Cohort study of silicon carbide production workers. Am J Epidemiol 2014; 140: 1009-15.

6 Bugge MD, Kjærheim K, Føreland S, Eduard W, Kjuus H. Lung cancer incidence among Norwegian silicon carbide industry workers: associations with particulate exposure factors. Occup Environ Med 2012; 69: 527-33.

7 Johnson NF, Hahn FF. Induction of mesothelioma after intrapleural inoculation of F344 rats with silicon carbide whiskers or continuous ceramic fi laments. Occup Environ Med 1996; 53: 813-16.

8 Nagai H, Okazaki Y, Chew SH, Misawa N, Yamashita Y, Akatsuka S, et al. Diameter and rigidity of multiwalled carbon nanotubes are critical factors in mesothelial injury and carcinogenesis. Proc Natl Acad Sci USA 2011; 108: E1330-38.

9 Sakamoto Y, Nakae D, Fukumori N, et al. Induction of mesothelioma by a single intrascrotal administration of multi-wall carbon nanotube in intact male Fischer 344 rats. J Toxicol Sci 2009; 34: $65-76$.

10 Takagi A, Hirose A, Futakuchi M, Tsuda H, Kanno J. Dose-dependent mesothelioma induction by intraperitoneal administration of multi-wall carbon nanotubes in p53 heterozygous mice. Cancer Sci 2012; 103: 1440-44.

11 Sargent LM, Porter DW, Staska LM, et al. Promotion of lung adenocarcinoma following inhalation exposure to multi-walled carbon nanotubes. Part Fibre Toxicol 2014; 11: 3.

12 Mercer RR, Scabilloni JF, Hubbs AF, et al. Distribution and fi brotic response following inhalation exposure to multi-walled carbon nanotubes. Part Fibre Toxicol 2013; 10: 33.

13 Shvedova AA, Kisin E, Murray AR, et al. Inhalation vs. aspiration of single-walled carbon nanotubes in C57BL/6 mice: infl ammation, fi brosis, oxidative stress, and mutagenesis. Am $J$ Physiol Lung Cell Mol Physiol 2008; 295: L552-65.

14 Pauluhn J. Subchronic 13-week inhalation exposure of rats to multiwalled carbon nanotubes: toxic eff ects are determined by density of agglomerate structures, not fi brillar structures. Toxicol Sci 2010; 113: 226-42. 
15 Shvedova AA, Yanamala N, Kisin ER, et al. Long-term eff ects of carbon containing engineered nanomaterials and asbestos in the lung: one year postexposure comparisons. Am J Physiol Lung Cell Mol Physiol 2014; 306: L170-82.

16 Sargent LM, Hubbs AF, Young SH, et al. Single-walled carbon nanotube-induced mitotic disruption. Mutat Res 2012; 745: 28-37.

17 Siegrist KJ, Reynolds SH, Kashon ML, et al. Genotoxicity of multi-walled carbon nanotubes at occupationally relevant doses. Part Fibre Toxicol 2014; 11: 1-15. 
$=\operatorname{login}$ 